Jowita Baran

Adrian Wołoszyn

Patrycja Król

Justyna Górska

Dominik Jabłoński

Uniwersytet Jagielloński

\title{
POLITYKA SENIORALNA MIASTA KRAKOWA A POTRZEBY BENEFICJENTÓW
}

\begin{abstract}
Senior policy of the city of Krakow and the needs of beneficiaries

The article presents a description of seniors' activity in Krakow in the light of social policy of ageing prepared by the city. The work focuses on comparing the prepared offer and verifying it with the beneficiaries expectations. Qualitative research was carried out to take a closer look at the senior needs. The issue of motivation to undertake classes was raised. Subcategories have been introduced, according to which seniors' activity patterns can be defined. Factors that prevent or make it difficult to take up activities are also presented - among others, the problem of selfexclusion of seniors from social life and gender related barriers, which limit the participation level in programs addressed to seniors.
\end{abstract}

Key words: activity, senioral policy, elderly people

\section{Wstęp}

Konsekwencje wynikające z procesu starzenia się społeczeństw europejskich, mimo wielu podjętych działań, nadal pozostają istotnym problemem polityk społecznych. Owe problemy wiążą się przede wszystkim z wydłużającą się średnią długością życia. W Polsce wynosi ona dla kobiet prawie 82 lata i 74 lata dla mężczyzn (GUS 2016). W tej perspektywie przed seniorami pojawia się konieczność zagospodarowania dużej ilości wolnego czasu, który mogą poświęcić na samorozwój i oddanie się pasjom. Czy jednak to robią? Miasto Kraków zdecydowało się na wprowadzenie rozbudowanego programu polityki senioralnej w odpowiedzi na potrzeby wynikające ze zmieniającej się struktury demograficznej mieszkańców. W związku z tymi faktami postanowiliśmy sprawdzić, jak wygląda aktywność krakowskich seniorów. W przeprowadzonym badaniu skupiliśmy się na wybranych aspektach tego zjawiska. Rozpoczynając od poznania 
oferty przygotowanej dla seniorów, sprawdzenia, czy jest ona zgodna z potrzebami beneficjentów, aż po próbę ustalenia, czy istnieją jakieś przeszkody do podejmowania takich działań. W pracy skupiliśmy się również na opisaniu ścieżek i wzorów aktywizacji osób starszych oraz na ustaleniu przyczyn braku podejmowania aktywności. Dodatkowo zainteresowało nas, czy seniorzy uważają miasto Kraków za miejsce, które odpowiada potrzebom osób starszych.

\section{Być osobą starszą w XXI wieku}

Starość jest pojęciem dość niejasnym. Problem stanowi tutaj arbitralność, z jaką możemy ją zdefiniować, co spowodowane jest tym, że wiek metrykalny nie pokrywa się z wiekiem biologicznym, funkcjonalnym i społecznym (Szukalski 2004: 11). Inną kwestią jest, że wejście w tak zwany „trzeci wiek” jest społecznie konstruowane (Mucha, Krzyżowski 2010: 251). Jednakże w powszechnym odczuciu początek starości wiąże się z momentem przejścia na emeryturę. W odniesieniu do Polski badania CBOS wykazały, że za średni wiek, w którym zaczyna się starość, uznaje się 63 lata (CBOS 2012). Za Haliną Worach-Kardas można zaznaczyć, że społeczne postrzeganie wieku wynika z kryterium ról społecznych pełnionych w kolejnych fazach życia (por. Worach-Kardas 1983). Z kolei Zofia Szarota wiąże ten moment w życiu człowieka ze zmianą statusu społecznego, a także ze zmianą jakości stosunków społecznych. Mówi się tu o „procesie stawania się człowiekiem starym”, wskazując rolę adaptacji do nowego etapu (Szarota 2004: 43). Proces ten jest determinowany przez dwa rodzaje czynników: wewnętrzne, czyli emocje, oczekiwania i motywy, oraz zewnętrzne: możliwości, obowiązki, przeciwności losu i działanie innych osób. Z kolei sama starość jest wypadkową oddziaływań biologicznych, psychologicznych oraz społeczno-kulturowych (wyróżnić tu można odpowiednio m.in. czynniki dziedziczne, historię życia, cechy osobowości oraz postawę wobec starości). Przy czym warto podkreślić, że w żadnym innym okresie los człowieka nie jest zależny w takim stopniu od jego charakteru, usposobienia, nawyków i umiejętności współżycia z ludźmi, ponieważ to te cechy są decydujące w kontaktach z innymi, co z kolei rzutuje później na możliwości współpracy i korzystania z ewentualnej ich pomocy (Szarota 2004: 46). Jest to o tyle ważne, że to starsi są bardziej podatni na negatywne wpływy środowiska. Są też bardziej od niego zależni, głównie ze względów zdrowotnych, co skutkuje między innymi ograniczeniem mobilności do określonego obszaru.

Na gruncie nauk społecznych powstało wiele teorii starzenia się. Można je podzielić na dwa główne nurty - makro- i mikrospołeczny. Pierwszy nurt czerpie z funkcjonalizmu, strukturalizmu lub teorii konfliktowych. W jego ramach podkreśla się istotność norm i ról społecznych, które wpływają na tożsamość i zachowanie osób starszych. Za Adamem Zychem (por. Zych 1999) wśród makrospołecznych teorii starzenia się należy wymienić teorie aktywności i wyłączania. Teoria aktywności została zaproponowana przez Ruth S. Cavan i w jej ujęciu proces starzenia się „jest zjawiskiem społecznym, które polega na gromadzeniu się napięć związanych z koncepcją obrazu siebie, które powstają wraz 
ze zmianą w pełnieniu ról” (Zych 1999: 37). W ramach tego ujęcia proponuje się możliwie największy poziom aktywności, ponieważ wiąże się ją bezpośrednio z określonym statusem społecznym i związanym z nim prestiżem. Z kolei teoria wyłączania wskazuje, że powodem społecznej izolacji, a także ograniczenia zakresu interakcji człowieka starszego z innymi członkami społeczeństwa, jest powszechny, podyktowany naturalnym pragnieniem, proces wycofywania się jednostki z życia społecznego. Głównymi teoretykami tego ujęcia byli Elaine Cumming i William E. Henry. Do makrospołecznych teorii starzenia się zaliczają się również: teoria stratyfikacji wieku oraz teoria politycznej ekonomii starości. Pierwsza, stworzona przez Matildę White Riley, Marylin Johnson oraz Anne Fonner, dzieli społeczeństwo na grupy wiekowe, odróżniające się dostępem do bogactwa, władzy i prestiżu, a także normami, wartościami oraz rolami społecznymi (Klimczuk 2012: 24). Nierówności między poszczególnymi grupami wiekowymi wynikają z faktu, że wiek jest traktowany jako kryterium wejścia do lub wyjścia z danego statusu społecznego. Natomiast teoria politycznej ekonomii starości wywodzi się z teorii konfliktu oraz marksistowskiej ekonomii politycznej (Klimczuk 2012: 25). Starość jest tutaj rozumiana jako rezultat polityki socjalnej oraz podziału pracy. To w ramach tej teorii często podkreśla się istnienie zjawiska ageizmu. Jako jej przedstawicieli można wskazać Carrolla Estes, Alana Walkera i Anne-Marie Guillemard.

Teorie mikrospołeczne skupiają się na indywidualnym wymiarze starzenia się. Można tu wskazać teorię wymiany, zgodnie z którą ludzie oceniają relacje z innymi na podstawie rachunku zysków i strat. Relacje są rozumiane jako wymiana dobrami, nie tylko ekonomicznymi, co wpływa na pozycję osób starszych w kontaktach z innymi (np. kontaktach międzypokoleniowych) (Szarota 2004: 47). Kolejną teorią z grupy mikrospołecznych jest podejście fenomenologiczne, które indywidualizuje proces starzenia się. Główną rolę w tworzeniu swojego obrazu starości przypisuje się samej jednostce, która ustala go w ramach interakcji z innymi (Szarota 2004: 47). Ponadto wyróżnić należy też teorię kompetencyjną, która uznaje, że zachowanie człowieka starszego jest wynikiem wymagań kierowanych wobec osób starszych oraz zasobów umożliwiających sprostanie im. Teoretycy tego ujęcia, wśród których możemy wymienić między innymi Ursulę Lehr, postulują podejmowanie działań mających na celu utrzymywanie samowystarczalności jednostki (Szarota 2004: 48). Ostatnim z przytoczonych przykładów niech będzie teoria Paula Baltesa zwana w skrócie SOK (Selekcja, Optymalizacja, Kompensacja), będąca silnie zakorzeniona w psychologii. Selekcja oznacza tutaj wybór modelu życia oraz celów, które człowiek chciałby zrealizować, a optymalizacja dotyczy wyboru odpowiednich środków i metod w celu realizacji wybranego modelu życia. Natomiast kompensacja wyraża się w zachowaniu elastyczności w momencie utraty środków lub utraty możliwości. Rozwój człowieka jest w tym ujęciu rozumiany jako proces trwający całe życie.

Współcześnie podejmuje się różnego rodzaju działania mające na celu sprostanie potrzebom osób starszych. Polityka społeczna wielu krajów nakierowana jest na wydłużanie pełnosprawnego i aktywnego życia seniorów w przestrzeni publicznej. Należy podkreślić, że społeczeństwa z dużym odsetkiem osób starszych charakteryzują się innymi potrzebami niż społeczeństwa młode (Mucha, Krzyżowski 2010: 249). Stąd też rośnie 
potrzeba modyfikacji, dostosowania i ciągłej ewaluacji polityk senioralnych. W Polsce powstają różne przedsięwzięcia, których celem ma być realizacja założeń dotyczących poprawy jakości życia seniorów. Można tutaj wskazać chociażby rozpowszechnianie się Uniwersytetów Trzeciego Wieku, upowszechnianie technologii cyfrowych wśród seniorów (Mucha, Krzyżowski 2010: 258) czy wdrażanie coraz to nowych polityk na poziomie miast.

Mimo pozytywnych zmian w jakości życia osób starszych, nadal wielu seniorów nie odnajduje się w tej roli. Dla części z nich trudne jest funkcjonowanie w społeczeństwie zorientowanym w większym stopniu na młodość. Według badań CBOS (CBOS, 2012) tylko 6\% respondentów niczego nie obawia się w związku ze starością. Znaczna większość (73\%) obawia się chorób, niedołężności czy utraty pamięci. Optymistycznie może natomiast nastrajać fakt, że odsetek osób obawiających się poczucia bycia niepotrzebnym spadł w porównaniu z wcześniejszymi badaniami i osiągnął 6\%. Przytoczone badanie wykazało też, że respondenci najchętniej wyobrażają sobie starość, mieszkając we własnym mieszkaniu, korzystając z doraźnej pomocy osób bliskich - rodziny, przyjaciół, sąsiadów. Wskazuje to na chęć pozostania samodzielnym, nie tracąc przy tym na więzach z najbliższą rodziną. W tym kontekście pojawia się koncepcja aktywnego starzenia, która jest jednym z głównych pojęć uwzględnianych w politykach społecznych (również w polityce senioralnej prowadzonej w Polsce) (Perek-Białas, Zwierzchowski 2014: 4). Z uwagi na potrzebę pomiaru poziomu wspomnianego aktywnego starzenia stworzony został Active Aging Index (AAI), który ma za zadanie określić stopień, w jakim wykorzystywany jest potencjał starszych osób oraz w jaki sposób można go jeszcze zagospodarować (Perek-Białas 2014: 34). Aktywne starzenie się oznacza starzenie się w dobrym zdrowiu jako pełnoprawny członek społeczeństwa. Ponadto towarzyszy mu społeczne zaangażowanie oraz większy zakres niezależności w codziennym życiu (Active Aging Index - Summary 2014 2015: 4). Niestety, jak wskazują statystyki z 2012 roku opracowane przy użyciu wspomnianego indeksu, Polska plasuje się nisko, jeśli chodzi o ogólny wynik (Perek-Białas 2014: 35). Analizując poszczególne aspekty indeksu aktywnego starzenia się, można stwierdzić, że szczególnie słabo wypada poziom społecznej partycypacji (27. miejsce Polski na 27 badanych krajów). Te wyniki potwierdzają potrzebę ciągłego monitorowania sytuacji osób starszych, a także skutków wprowadzanych rozwiązań polityk senioralnych.

Starzenie się społeczeństw, wydłużenie trwania ludzkiego życia, konieczność zagospodarowania aktywności osób wieku poprodukcyjnego oraz zmiana modelu opieki nad ludźmi starszymi są czynnikami, które nadają kierunek badaniom wykonywanym przez przedstawicieli wielu nauk (Szarota 2004: 94). Procesy te są też coraz większym polem do popisu dla takich dziedzin jak gerontologia edukacyjna (geragogika), która „zajmuje się edukacją gerontologiczną rozumianą jako usystematyzowany przekaz wiedzy na temat interdyscyplinarnych zagadnień charakteryzujących procesy starzenia się i fazę życia, jaką jest starość właściwa” (Szarota 2013: 11) czy „wychowaniem ludzi starzejących się i starych". Dziedzina ta jest niezbędna przy dbaniu o odpowiednie starzenie się.

Podsumowując, w Polsce i na świecie rośnie liczba osób starszych. Zjawisko to sprawia, że procesy depopulacyjne i starzenie się społeczeństw stają się najważniejszymi 
przekształceniami demograficznymi XXI wieku. Należy więc podjąć kroki adaptacyjne, przystosowujące zarówno seniorów, jak i resztę społeczeństwa do aktywnego funkcjonowania w wydłużającej się trzeciej fazie życia.

\section{Polityka społeczna w mieście Kraków}

Aktualny zarys polityki senioralnej miasta znajduje się w „Programie Aktywności Społecznej i Integracji Osób Starszych 2015-2020" (PAISOS). Szczególny nacisk położono w nim na ciągłość w edukacji osób starszych, która ma im umożliwić nie tylko zachowanie zdrowia, ale również aktywności i niezależności do późnych lat życia. Ważnym aspektem programu jest zapobieganie wykluczeniu społecznemu seniorów - $\mathrm{w}$ tym aktywizacja do działania na rzecz innych. Jednak sama edukacja osób starszych nie wystarczy, aby program mógł odnieść sukces. Podkreślano, że należy kształcić całe społeczeństwo, niezależnie od wieku, i już od najmłodszych lat uczyć, czym jest starość i jak przebiega proces starzenia - nie tylko po to, aby przygotować się na ten etap życia, ale przede wszystkim, aby nauczyć się zrozumienia wobec seniorów.

Możemy wyróżnić trzy jednostki realizujące kompleksowo założenia polityki senioralnej Krakowa. Najważniejsze z nich to Centra Aktywności Seniora (CAS). Według założeń programu PAISOS mają one pełnić funkcję integracyjną, aktywizacyjną i prozdrowotną. Ich oferta ma składać się z zajęć pozwalających seniorom na rozwijanie ich zainteresowań i nabywanie nowych kompetencji i umiejętności. CAS-y mają za zadanie zaoferować seniorom alternatywne sposoby spędzania wolnego czasu, które nie przyczyniają się do odosobnienia osób starszych. Dane za 2017 rok wskazują, że w Krakowie znajduje się 25 CAS-ów. Docelowo ma ich powstać 54, po trzy w każdej dzielnicy. Najczęściej tworzone są z inicjatywy organizacji pozarządowych.

Drugą instytucją realizującą cele PAISOS są Krakowskie Centra Seniora. Pierwotnie ich działalność ograniczała się do dyżurów wolontariuszy, którzy udzielali seniorom informacji na temat skierowanej do nich oferty zajęć w mieście. Z czasem zaczęły ewoluować, wolontariusze działający w KCS zaczęli organizować zajęcia dla seniorów oraz stworzyli projekt Letniej Akademii Seniora. Obecnie KCS wraca do swojej pierwotnej formy, czyli dyżurowania w celu udzielania informacji seniorom.

Za ostatnią instytucję spełniającą cele PAISOS możemy uznać Radę Krakowskich Seniorów. Powołano ją w 2014 roku jako organ doradczy i konsultacyjny w kwestii umożliwienia osobom starszym wpływania na politykę senioralną miasta i działania na rzecz seniorów. Warunkiem kandydowania jest ukończenie 60. roku życia, poparcie organizacji działającej na rzecz seniorów oraz zamieszkiwanie na terenie miasta Krakowa.

Miasto Kraków oferuje również szereg cyklicznych inicjatyw skierowanych do krakowskich seniorów. Jedną z nich jest akcja „Miejsce przyjazne seniorom”. W jej ramach co roku przyznawane są certyfikaty dla instytucji, które w swojej działalności uwzględniają potrzeby osób starszych. Mogą to robić zarówno poprzez dostosowanie 
infrastruktury, jak i przygotowania specjalnej oferty. Dzięki otrzymaniu certyfikatu miejsca te mogą liczyć na promocję w lokalnych mediach.

Na terenie miasta Krakowa działa również dziesięć Uniwersytetów Trzeciego Wieku. Celem ich powstania była aktywizacja osób starszych, umożliwienie im rozwijania własnych zainteresowań oraz wykorzystanie ich potencjału na rzecz społeczeństwa. Słuchacze mogą uczestniczyć nie tylko w wykładach, ale w szeregu innych zajęć, takich jak zajęcia komputerowe, lektoraty językowe czy koła naukowe.

W Krakowie odbywają się również Senioralia. To wydarzenie, którego zadaniem jest promowanie działań seniorów oraz ich osiągnięć w różnych dziedzinach ich aktywności. Wśród celów szczegółowych wymienione zostały: aktywizacja i edukacja osób starszych, promowanie integracji wewnątrz- i międzypokoleniowej oraz partycypacja społeczna osób starszych.

\section{Metodologia}

Badanie zostało przeprowadzone przez studentów socjologii I stopnia w ramach obozu badawczego „W wielopokoleniowym społeczeństwie”, we współpracy z Urzędem Miasta Krakowa, pod opieką dr Magdaleny Ślusarczyk. Za populację badawczą wybrano mieszkańców i mieszkanki Krakowa powyżej 60. roku życia, nieaktywnych zawodowo. Przyjęto takie kryteria, gdyż są one charakterystyczne dla grupy będącej głównymi beneficjentami programów aktywizacji seniorów oferowanych na terenie miasta Krakowa. Ponieważ przeprowadzone badania miały charakter jakościowy, a badana populacja posiada specyficzną charakterystykę, posłużono się celowym doborem próby. Dobór ten charakteryzuje się wykorzystaniem własnej wiedzy na temat badanej populacji i dobraniu respondentów na jej podstawie (Babbie 2004: 205).

Respondenci zostali podzieleni na dwie podgrupy: seniorów, rekrutowanych wśród uczestników zajęć kierowanych do osób starszych, i seniorów spoza grona osób korzystających z oferty krakowskich instytucji, czyli osoby nieaktywne. Taki podział umożliwił objęcie obszarem badania zarówno seniorów korzystających z krakowskich programów aktywizacyjnych, jak i tych niezaangażowanych w ofertę zajęć skierowanych do seniorów. Dodatkowo przeprowadzono wywiady z ekspertami, czyli osobami prowadzącymi lub koordynującymi zajęcia skierowane dla seniorów organizowane w ramach danych ośrodków (m.in. Centrów Aktywizacji Seniorów, Klubów Seniora czy Krakowskiego Centrum Seniora). Włączenie ekspertów do badania pozwoliło na szersze spojrzenie na działanie owych instytucji.

Badanie zostało przeprowadzone w okresie od listopada 2017 do stycznia 2018 roku. Zrealizowano 12 zogniskowanych wywiadów indywidualnych z seniorami oraz sześć częściowo ustrukturalizowanych wywiadów indywidualnych z ekspertami.

W badaniu zastosowano słownik pojęciowy wykorzystywany w dotychczasowych badaniach aktywności społecznej seniorów, aby móc odnosić się do wyników innych badań, obejmujących podobne zagadnienia. Projekt zrealizowano przy zastosowaniu 
metod jakościowych, które, jak podaje Uwe Flick (2010: 22): „wychodzą od koncepcji społecznego tworzenia badanych rzeczywistości, skupiają się na punktach widzenia uczestników, ich codziennych praktykach oraz wiedzy dotyczącej przedmiotu badania. $\mathrm{W}$ związku z tym również stosowane metody powinny mieć wystarczająco otwarty charakter, by umożliwić zrozumienie procesu lub relacji”. Zdecydowaliśmy się na indywidualne wywiady zogniskowane ze względu na otwarty i eksploracyjny charakter badania. Wybór metody został podyktowany chęcią uzyskania pogłębionej wiedzy w zakresie badanego tematu. Chcieliśmy dotrzeć do indywidualnych doświadczeń naszych respondentów w aktywizacji i motywacjach do jej podjęcia. Wywiady indywidualne pozwalają w najlepszy sposób dotrzeć do takiego rodzaju informacji (por. Babbie 2008: 331-332). Istotne było zbudowanie zaufania z Respondentami.

W wywiadach z ekspertami zdecydowano się na częściowo ustrukturalizowane wywiady indywidualne. Pozwoliło to na pogłębienie ważnych w badaniu kwestii, jednocześnie zapewniając możliwość standaryzacji zagadnień.

Dobór respondentów natrafił na problemy: okazało się, że większość seniorów to osoby już zaangażowane, dotarcie do osób nieaktywnych było znacznie trudniejsze. Mamy również do czynienia $z$ nadreprezentacją kobiet, podobne sytuacje miały miejsce też w innych badaniach, co potwierdza tezę o częstszej aktywizacji kobiet (CBOS 2012; CBOS 2016; Czapiński, Błędowski 2014: 70).

W badaniu skupiliśmy się na kilku wybranych kwestiach dotyczących aktywizacji seniorów w Krakowie. Przede wszystkim podjęliśmy próbę scharakteryzowania cech demograficzno-społecznych seniorów, którzy angażują się w różne formy spędzania wolnego czasu. Kolejnym krokiem było pytanie o determinanty podjęcia takiej aktywności. Z tym z kolei wiąże się zbadanie ścieżek, jakimi przebiega wspomniana aktywizacja osób starszych, oraz wzory aktywności, jakie można wśród nich wyróżnić, a więc ustalenie okoliczności, które skłoniły badanych do skorzystania z zorganizowanych form spędzania wolnego czasu. Celem była tutaj próba wskazania czynników, które mogą pozytywnie lub negatywnie wpływać na podejmowanie przez badaną grupę aktywności. W badaniu postanowiliśmy się pochylić również nad kwestią oferty zajęć dla seniorów. Stopień, w jakim odpowiada ona rzeczywistym potrzebom seniorów, znacząco wpływa na skuteczność działań instytucji i ośrodków oferujących zajęcia dla seniorów, co sprawia, że jest to kwestia istotna badawczo. Interesowały nas też sposoby docierania do seniorów $\mathrm{z}$ ofertą i skuteczność takiego działania.

$\mathrm{Z}$ uwagi na fakt, że badanie objęło również wywiady z koordynatorami zajęć w ośrodkach zajmujących się aktywizacją seniorów, postanowiliśmy również zestawić wypowiedzi seniorów i ekspertów. Ostatecznie postawiliśmy sobie za cel znalezienie odpowiedzi na następujące pytania badawcze:

1. Jaka jest oferta zajęć dla seniorów?

2. Czy oferta odpowiada na potrzeby seniorów?

3. Jakie są sieci i ścieżki aktywizacji?

4. Jakie są wzory aktywności seniorów? 
5. Jakie są przeszkody w aktywizowaniu się seniorów?

6. Czy Kraków jest miastem przystosowanym do potrzeb seniorów?

\section{Przygotowana oferta zajęć a potrzeby seniorów}

Odpowiednio skonstruowana oferta, która odpowiada potrzebom i zainteresowaniom seniorów, jest jednym z głównych elementów udanej aktywizacji seniorów. W znacznym stopniu decyduje ona o żywotności każdej instytucji, której działalność jest skierowana do osób starszych, tym samym stawiając przed nimi zadanie odpowiedniego jej dostosowania. Działania podejmowane w tym celu można podzielić na dwa typy. Jeden z nich to dopasowywanie oferty na bieżąco. Ten sposób zdaje się dominować w mniejszych ośrodkach, gdzie zajęcia są organizowane w sposób mniej sformalizowany. Jak dowiadujemy się od koordynatorki zajęć Miejskiego Dziennego Domu Pomocy Społecznej ${ }^{1}$ nr 3 w Krakowie 2 : „To jest takie wyczucie, że widzimy, co potrzebuje w danej sytuacji senior i jakby staramy się podnieść tę poprzeczkę". Podobnie jest w Ośrodku Wsparcia dla Osób Starszych Caritas Archidiecezji Krakowskiej, gdzie oferta konstruowana jest: „ze względu na zainteresowania seniorów, którzy też nam podpowiadają, co chcą robić”.

Widoczna jest tutaj interakcja, która zachodzi między organizatorami i prowadzącymi zajęcia a seniorami, co może pozytywnie wpływać na zaangażowanie seniorów. Jest to z pewnością również najłatwiejsza metoda tworzenia oferty. Jednakże w świetle wypowiedzi niektórych seniorów, którzy nie czują się,osobami starymi” i którzy uważają, że oferta nie jest dla nich, warto się zastanowić, czy tworzenie zajęć wyłącznie na podstawie „wyczucia” nie sprawia, że oferta staje się dostosowana de facto wyłącznie do seniorów z przedziału wiekowego, który akurat dominuje w danej instytucji - tym samym wykluczając z kręgu zainteresowanych część osób z dolnej granicy wieku emerytalnego.

Istnieje również inny sposób tworzenia ofert, o którym wspomniała kierowniczka Działu Edukacji, Nauki i Badań Wojewódzkiej Biblioteki Publicznej, będąca również koordynatorem Szkoły Aktywnego Seniora. Organizacja ta korzysta zarówno z takich metod, jak badanie satysfakcji, jak i z mniej formalnych, wśród których można wymienić bezpośrednie rozmowy z seniorami czy wymianę doświadczeń. Ponadto pracownicy tej instytucji uwzględniają dorobek różnego rodzaju konferencji, które mogą być inspiracją do wdrażania nowych ofert. Tutaj podejście do kwestii tworzenia oferty jest bardziej kompleksowe, a organizatorzy posiłkują się różnymi źródłami. Nie zdają się wyłącznie na sugestie uczestników zajęć, ale jednocześnie stanowią one podstawę, na której tworzy się ofertę.

Kwestią, którą należy również poruszyć przy temacie konstruowania ofert, jest fakt, że niektóre organizacje nawet jeśli rozpoznają potrzeby seniorów, to czasem nie potrafią ich wcielić w życie. Wskazuje się przykładowo na zbyt niskie środki finansowe, które

\footnotetext{
${ }^{1}$ MDDPS to specyficzna nazwa instytucji obowiązująca w Krakowie.

${ }^{2}$ Dalej obowiązuje nazwa: Miejski Dzienny Dom Pomocy Społecznej.
} 
otrzymują centra aktywności seniora, czy ich ograniczenia przestrzenne związane $\mathrm{z}$ warunkami lokalowymi.

Kolejnym wątkiem jest popularność zajęć. Z jakiego typu zajęć seniorzy najchętniej korzystają? Z wypowiedzi ekspertów można wnioskować, że jest to uwarunkowane charakterem danej instytucji oraz profilem seniorów, do których dana instytucja ma zamiar docierać. I tak w Szkole Aktywnego Seniora dominują zajęcia komputerowe, co znajduje odbicie w wypowiedziach seniorów. Cieszą się one największą popularnością i jednocześnie są wskazywane jako te zajęcia, z których instytucja jest najbardziej dumna. Wypowiedź koordynatorki zajęć Miejskiego Dziennego Domu Pomocy Społecznej, gdzie dominuje terapia zajęciowa, codzienne spotkania grona seniorów czy wydarzenia tematyczne (np. Wielkanoc, Walentynki) potwierdza, że popularność danego typu zajęć jest uwarunkowana profilem seniorów, na których nastawiona jest dana instytucja. Do grona popularnych zajęć należy też z pewnością zaliczyć zajęcia rekreacyjno-sportowe, o których wspomniał wiceprzewodniczący Rady Krakowskich Seniorów. Natomiast potrzeby osób najbardziej wykluczonych zdają się rzadko uwzględniane w ofertach. Wspomina o tym koordynatorka zajęć Krakowskiego Centrum Seniora, która sugerowała powstanie grup działających przy parafiach, które mogłyby poświęcić czas osobom wykluczonym oraz zaoferować wysłuchanie i rozmowę.

Podsumowując, należy podkreślić, że chęć stworzenia jak najlepszej oferty nie może przesłonić prostego faktu, że często seniorzy nie przywiązują zbyt dużej wagi do rodzaju zajęć, ponieważ zależy im bardziej na zwyczajnym spędzeniu czasu w towarzystwie innych osób.

\section{Sieci i ścieżki aktywizacji seniorów}

Przez sieci i ścieżki aktywizacji seniorów rozumiemy zarówno sposoby, w jaki seniorzy zdobywają informacje na temat oferty kierowanej do nich, jak i kanały, którymi instytucje posługują się w celu dotarcia do seniorów i zachęcenia ich do skorzystania z programów przez siebie przygotowanych. Z kolei pojęcie ścieżek aktywizacji odnosi się do motywacji oraz okoliczności, które można wyróżnić jako przyczyniające się do zaangażowania lub jego braku ze strony seniorów.

Instytucje w różny sposób docierają do beneficjentów. Jednymi z najczęściej wymienianych metod były: „marketing szeptany”, czyli polecenia danych ośrodków przez znajomych, strony internetowe, media społecznościowe, ulotki, plakaty, tablice ogłoszeniowe oraz za pośrednictwem innych instytucji (np. Miejski Ośrodek Pomocy Społecznej). Kanały komunikacji, jakimi posługują się instytucje, to: strony internetowe, informatory, foldery i gazety, audycje radiowe, rozmowy telefoniczne oraz tak zwana poczta pantoflowa, czyli informacje przekazywane seniorom przez innych seniorów. Ta ostatnia była wskazywana jako jedna z najskuteczniejszych metod. Jako główne wady obecnych kanałów komunikacji wskazano niemożność dotarcia do wszystkich seniorów oraz poinformowania ich odpowiednio wcześnie o danych wydarzeniach. Wśród propozycji 
nowych kanałów, które można stworzyć, pojawiła się platforma do komunikacji między instytucjami a seniorami, ponieważ e-maile często do nich nie docierają. Innym pomysłem są tradycyjne ulotki, które rozdawane seniorom $w$ instytucjach, mogłyby być przez nich dalej przekazywane. W ten sposób stworzono by możliwość dotarcia do osób mniej aktywnych i niekorzystających z oferty skierowanej do seniorów. Mały format ulotki miałby ułatwić jej przechowywanie oraz stanowić formę przypomnienia o miejscach aktywizacji czy wydarzeniu. Krakowskie instytucje starają się dotrzeć do seniorów w różnych częściach miasta. Zgodnie z informacją udzieloną przez wiceprzewodniczącego Rady Krakowskich Seniorów, w planach jest otwarcie kolejnych CAS-ów w różnych dzielnicach, tak aby w każdej były minimum trzy. Również w przypadku Krakowskiego Centrum Seniora otwarto filię na Wielopolu, ponieważ ta w Nowej Hucie okazała się niewystarczająca. W przypadku innych instytucji, takich jak Wojewódzka Biblioteka Publiczna przy ulicy Rajskiej, wskazuje się na rolę komunikacji miejskiej, która powinna być dostosowana do osób starszych, tak aby ułatwić im przemieszczanie się między domem a interesującą ich instytucją. W zależności od charakteru instytucji docieranie do osób wykluczonych odbywa się w inny sposób. Początkowo CAS-y powstawały na obrzeżach miast, jednak frekwencja w tych miejscach okazała się niewystarczająca. W przypadku Miejskiego Dziennego Domu Pomocy Społecznej pracownicy mogą jedynie przekazać sprawę do pracowników socjalnych, jeżeli dostaną niepokojący sygnał. Część instytucji wskazuje, że nie stara się docierać do seniorów wykluczonych, skupiają się raczej na tych, którzy sami się do nich zgłaszają.

Wśród motywacji, które wpłynęły na decyzję badanych o skorzystaniu z oferty skierowanej do seniorów, należy wymienić potrzebę utrzymania kontaktów. Potrzeba ta okazuje się głównym czynnikiem mobilizującym do podjęcia aktywności. Moment zakończenia aktywności zawodowej wiąże się z potrzebą organizacji czasu na nowo. Z jednej strony jest to dużym wyzwaniem dla seniorów $\mathrm{i}$, jak wynika $\mathrm{z}$ wypowiedzi badanych na temat innych osób starszych niepodejmujących żadnej aktywności, nie wszystkim udaje się odnaleźć w nowej roli. Jest to pewien proces adaptacji, który z drugiej strony może okazać się udanym i dającym nowe możliwości, ponieważ jest to czas, kiedy seniorzy mogą rozwijać swoje zainteresowania. Czynnikiem, który może wpłynąć pozytywnie na wspomniany proces adaptacji, jest posiadanie przez seniorów kapitału społecznego, który objawia się kontaktem z osobami, które już skorzystały z ofert skierowanych do seniorów. Dzięki temu senior dowiaduje się od osób ze swojego otoczenia o możliwościach spędzania wolnego czasu, co, jak wynika z wypowiedzi badanych, jest najskuteczniejszym sposobem na docieranie do osób starszych. W procesie aktywizacji dużą rolę odgrywają też czynniki psychologiczne. Na podstawie przeprowadzonych wywiadów można zasugerować, że czynniki psychologiczne mogą wyrównywać niedostatki kapitału społecznego. W badaniu widoczne to było na przykładzie seniora, który po przejściu na emeryturę oraz po śmierci małżonki postanowił samodzielnie poszukać miejsca, gdzie mógłby spędzać wolny czas. Jednocześnie czynniki psychologiczne potrafią też być barierą, która sprawia, że mimo stwarzania możliwości niektórzy seniorzy niemal całkowicie wycofują się z życia społecznego. Kwestia ta pojawiała się w wypowiedziach 
badanych opisujących znane im osoby, które nigdy nie korzystały z omawianych form aktywności. Na pytanie o to, jak można by zachęcić takie osoby, badani sugerowali zaangażowanie wolontariuszy, którzy docieraliby bezpośrednio do miejsc zamieszkania seniorów i przedstawiając ofertę, zachęcali do podjęcia aktywności. Inny sugerowany przez badanych pomysł to umieszczenie w takich miejscach jak przychodnie lepiej widocznych informacji na temat oferty.

\section{Wzory aktywności seniorów}

Z przeprowadzonych wywiadów z seniorami wynika, że najchętniej wybierają oni zajęcia z obsługi komputera i Internetu, zajęcia językowe, sportowe, filmowe i dyskusyjne oraz wspólne wycieczki organizowane przez instytucje zajmujące się aktywizacją seniorów. Wizerunek seniorów, który wyłania się z rozmów z przedstawicielami krakowskich instytucji, jest spójny z przedstawionymi preferencjami przebadanych respondentów. Eksperci wskazują, że osoby starsze najchętniej wybierają zajęcia komputerowe i językowe. Interesującą kwestią wydaje się duża popularność zajęć związanych z szeroko rozumianym podtrzymywaniem sprawności fizycznej, takich jak: nordic walking, basen, gimnastyka oraz rehabilitacja. Nie wszystkie przebadane instytucje oferują w swoim programie takie zajęcia. $Z$ wywiadów można jednak wywnioskować, że wszędzie tam, gdzie są dostępne takie formy aktywności, cieszą się one dużą popularnością. Seniorzy, którzy brali udział w zajęciach fizycznych, skarżyli się na niewielką ilość miejsc w grupach i wskazywali, że należy rozszerzyć ofertę. Podkreślali, że jest to bardzo ważne, aby osoby starsze brały udział w zajęciach fizycznych. Seniorzy chętnie również wyjeżdżają na wspólne jedno- i kilkudniowe wycieczki. Dodatkowo popularne jest wspólne spędzanie czasu poza murami instytucji. Wyjścia na wspólne spacery, zwiedzanie lub uczestnictwo w wydarzeniach kulturalnych cieszą się zainteresowaniem, na co wskazywali przedstawiciele przebadanych instytucji. Formy spędzania czasu poza instytucją oraz spotkania kulturalne zainteresowałyby, według deklaracji, jednostki zwykle niekorzystające $\mathrm{z}$ oferty.

Z wypowiedzi przedstawicieli różnych instytucji i organizacji wynika, że częściej $\mathrm{z}$ różnego rodzaju aktywności korzystają kobiety. W wywiadach pojawiła się sugestia braku odpowiednich zajęć dla mężczyzn, na co wskazywała koordynatorka zajęć w Ośrodku Wsparcia dla Osób Starszych Caritas Archidiecezji Krakowskiej: „próbowaliśmy różnych sposobów ściągnięcia panów i jakoś nigdy to się nie udaje. Mają też inne zainteresowania, inne sposoby spędzania wolnego czasu". Mimo że wiek i płeć są tutaj istotną zmienną, to jednak cechy demograficzno-społeczne zdają się nie odgrywać tak istotnej roli w procesie aktywizacji seniorów. Można tutaj przytoczyć wypowiedź koordynatorki zajęć Miejskiego Dziennego Domu Pomocy Społecznej: „każdy, obojętnie, czy ma wyższe, czy podstawowe wykształcenie, ma takie same potrzeby bycia $\mathrm{z}$ drugim człowiekiem (...), bycia, czucia się potrzebnym". 
Przebadani seniorzy w większości deklarują swoją aktywność. Głównie uczestniczą w zajęciach oferowanych przez Centra Aktywności Seniora. Pojedyncze osoby wybierają także zajęcia w instytucjach niekierujących swojej oferty bezpośrednio do seniorów; dotyczy to zwłaszcza zajęć sportowych, takich jak joga czy basen. Może to być spowodowane ubogą ofertą, która jest nieatrakcyjna dla seniorów, lub wynika to $\mathrm{z}$ braku dostępnych miejsc w ramach instytucji. Osoby aktywne deklarują, że częstotliwość uczęszczania na zajęcia jest duża i nie starczyłoby im czasu na udział w większej liczbie zajęć.

Wywiady z respondentami oraz przedstawicielami instytucji pozwoliły wyodrębnić trzy różne kategorie seniorów podzielone ze względu na stopień aktywności. Można wyróżnić pewne typy idealne, które na potrzeby badania zostały określone jako: klienci, zaangażowani oraz niekorzystający. Pierwszą z nich, najbardziej liczną, stanowiły osoby biorące udział w wielu różnych inicjatywach. Zostały one określone przez nas mianem klientów. Są to uczestnicy zajęć, którzy chętnie przychodzą, korzystają z oferty, jednak nie angażują się w organizację zajęć. Najczęściej biorą udział w wielu aktywnościach w różnych instytucjach, wybierając dla siebie najbardziej atrakcyjne spotkania. W badaniu przeważały osoby o takim sposobie korzystania z oferty. Do drugiej kategorii zalicza się osoby, które nie tylko korzystają z przygotowanych zajęć, ale również aktywnie biorą udział w ich przygotowaniu. Działaniami takimi są na przykład organizowane w Wojewódzkiej Bibliotece Publicznej w Krakowie spotkania podróżnicze. Podczas takiego wydarzenia chętne osoby z pomocą prezentacji multimedialnej opowiadają grupie o swoich podróżach. Ostatnią grupę stanowily osoby niekorzystające z oferty. Są to osoby, które nie odczuwają potrzeby brania udziału w aktywnościach. W badaniu jedna $\mathrm{z}$ respondentek, osoba zamężna, tłumaczyła, że nie ma czasu na dodatkowe aktywności, ponieważ zajmuje się prowadzeniem domu oraz opieką nad starszym członkiem rodziny. Ponieważ grupę respondentów stanowily w większości osoby, które chętnie uczestniczą w zajęciach, poprosiliśmy je również, aby opowiedziały, czy znają osoby, które nie korzystają z przygotowanej dla nich przez instytucje oferty. Wielu z badanych seniorów przyznawało, że znają również takich seniorów, a na możliwe przyczyny takiego stanu rzeczy najczęściej wskazywano samowykluczenie się seniorów oraz lęk przed brakiem wystarczających umiejętności.

Jak wynika z wypowiedzi ekspertów, za główne czynniki determinujące podjęcie aktywności należy uznać przede wszystkim stan zdrowia oraz cechy charakteru. Wiceprzewodniczący Rady Krakowskich Seniorów, wykorzystując język specjalistów zajmujących się aktywizacją seniorów, zaproponował rozróżnienie na trzy grupy seniorów. Pierwszą stanowią osoby o względnie wysokim poziomie sprawności. Są to seniorzy z grupy go-go - osoby charakteryzujące się umiarkowanie dużą aktywnością, chęcią podróżowania i poznawania nowych rzeczy, rozwijania swojego hobby. Aktywność ta przejawia się najczęściej po przejściu na emeryturę i zazwyczaj trwa do 75. roku życia. Seniorzy z grupy slow-go to osoby w wieku od 75. do 85. roku życia. Aktywność w tym wieku znacząco spada, osoby te przeważnie spędzają czas wolny w zaciszu domowym lub w bliskiej i znanej im okolicy. Oprócz tego seniorzy aktywizujący się charakteryzują się dużą potrzebą bycia w grupie i podtrzymywania kontaktów międzyludzkich. Ilustruje 
to wypowiedź koordynatorki zajęć Miejskiego Dziennego Domu Pomocy Społecznej: „(...) osoba chętna do tego, by coś jeszcze ze swoim życiem zrobić, chętna osoba nie chce zamykać się w czterech ścianach, nie chce być jakby pozbawiona kontaktu właśnie z drugim człowiekiem (...)”. Trzecią kategorię seniorów stanowią osoby z grupy no-go. Główną barierą jest stan zdrowia, ponieważ są to osoby, które przekroczyły granicę około 85 lat i potrzebują opieki medycznej oraz pomocy w codziennym funkcjonowaniu.

\section{Przeszkody w aktywizowaniu się seniorów}

Podczas rozmów poruszony został między innymi temat braku aktywności wśród seniorów. Znaczną większość respondentów stanowiły osoby aktywne i zaangażowane, które ze względu na trudność w dotarciu do osób niezaangażowanych zapytaliśmy o znajomość osób niewykazujących zainteresowania ofertą aktywizującą oraz na wskazanie możliwych przyczyn takiego zachowania. Argumenty respondentów można podzielić na dwie grupy - związane z fizycznymi ograniczeniami oraz ograniczeniami natury psychologicznej.

Do pierwszej kategorii można zaliczyć wskazywane przez badanych problemy ze zdrowiem (również stany depresyjne), podeszły wiek oraz kłopotliwe dojazdy. Wskazywano również na częste wizyty u lekarzy, które mogą kolidować z terminem zajęć. Znacznie częściej wskazywano jednak na problemy związane z ograniczeniami natury psychologicznej. Należą do nich przede wszystkim: brak motywacji, lęk, wycofanie się $\mathrm{z}$ aktywnego życia, brak zorientowania na swoje potrzeby, przekładanie potrzeb rodziny nad swoje, brak życia towarzyskiego. Pojawiły się również głosy o samowykluczeniu się seniorów.

Fizyczne ograniczenia wynikające $\mathrm{z}$ wieku oraz niepełnosprawności seniorów stanowią dużą przeszkodę do podejmowania aktywności. Istotny wydaje się tutaj problem związany z komunikacją miejską, w wielu przypadkach wciąż niedostosowaną do potrzeb tej grupy wiekowej. Seniorzy mówią głównie o stromych wejściach do tramwajów wysokopodłogowych. W przypadku osób niepełnosprawnych pojawiają się także głosy o niemożności dostania się do miejsc, gdzie zajęcia się odbywają, między innymi ze względu na nieodpowiednie warunki infrastrukturalne budynków.

Jak wspomniano, w wielu wypowiedziach respondenci wskazywali także na aspekt psychologiczny ograniczeń. Jednym z głównych powodów unikania aktywizacji jest problem samowykluczenia, który wiąże się między innymi z lękiem przed kontaktem z nową grupą czy obawami związanymi z niewystarczającymi umiejętnościami.

Również wśród aktywnych seniorów pojawiały się głosy, że zdarza im się rezygnować z zajęć ze względu na swój podeszły wiek. Jest to subiektywne poczucie bycia w nieodpowiednim wieku na niektóre aktywności. Jedna z respondentek, która chętnie podejmuje różne aktywności, między innymi uczestnicząc regularnie w zajęciach jogi, przyznała, że zdarza się jej odczuwać dyskomfort ze względu na swój wiek: „Czasami 
gdzieś jestem nawet zapraszana do tych młodych ludzi, czasami aż rezygnuję, zwłaszcza jak jest to międzynarodowa grupa, to mnie to trochę wyhamowuje" [Hanna].

Głosy o samowykluczeniu pojawiały się również w wypowiedziach przedstawicieli instytucji, na przykład w wypowiedzi kierowniczki Działu Edukacji, Nauki i Badań Wojewódzkiej Biblioteki Publicznej, która jest również koordynatorem Szkoły Aktywnego Seniora: „Mężczyźni mają zauważalny problem z tym, że nie chcą przyznać, że czegoś nie wiedzą, na przykład $\mathrm{z}$ komputerem, więc wolą ignorować fakt, że komputer jest potrzebny". Jak widać, problem ten może mieć wymiar genderowy i stanowić realną przeszkodę w rozpoczęciu aktywizowania się w podeszłym wieku.

Choć większość badanych podkreślała w swoich wypowiedziach, że miasto Kraków może się pochwalić bogatą ofertą skierowaną do osób starszych, to pojawiły się również głosy bardziej krytyczne. Respondenci chwalili kursy nauki języka angielskiego oraz organizowane przez różne instytucje kursy podnoszące kwalifikacje komputerowe. Dostrzegali również szeroką ofertę kulturalną. Pojawiły się jednak wypowiedzi, z których można wnioskować, że oferta jest budowana na stereotypowym postrzeganiu potrzeb osób starszych oraz że nie jest ona w pełni dopasowana do potrzeb seniorów. Jako najbardziej zaniedbaną kategorię aktywności respondenci jednogłośnie wskazywali ofertę zajęć sportowych i podtrzymujących sprawność fizyczną. W świetle przedstawionych wyników badań w części teoretycznej, gdzie nadwaga i otyłość są jednym z większych problemów polskich seniorów, jest to ważny wniosek, który należy wziąć pod uwage przy planowaniu przyszłych zajęć dla osób starszych.

Niektórzy z seniorów, z którymi przeprowadzono wywiady, obawiają się etykietowania ich jako osoby „stare”. Z tym też wiąże się ich niechęć do uczestnictwa w zajęciach oferowanych przez Centra Aktywności Seniora oraz inne instytucje posiadające ofertę skierowaną do seniorów. Osoby te uważają, że uczestnictwo w zajęciach kierowanych do ich grupy wiekowej spowodować może ograniczenie kontaktów jedynie do osób starszych i rówieśników. One natomiast chciałyby zwiększyć poziom swoich interakcji $\mathrm{z}$ młodszą grupą wiekową. Respondenci będący w dolnej granicy wieku emerytalnego nie mają subiektywnego poczucia bycia seniorem. Uważają, że oferta nie jest przeznaczona dla nich.

\section{Ocena miasta}

Na najbardziej ogólne i jednocześnie podsumowujące pytanie, czy Kraków jest miastem przyjaznym dla seniorów, wszyscy respondenci odpowiedzieli twierdząco. Podkreślali wyjątkowość miejsca, znaczenie historyczne i kulturalne oraz rozwój, jaki dokonał się w ciągu ostatnich kilkunastu lat. Duża część osób badanych zaznaczyła, że dopiero teraz, będąc na emeryturze i nie mając obowiązku pracy, doceniają walory kulturalne miasta. $\mathrm{Z}$ narracji badanych wyłania się przekonanie, że Kraków oferuje niespotykanie dużo możliwości dla osób, które chcą z nich skorzystać. Jedna z seniorek podsumowuje to słowami: „każdy senior to musi dbać o siebie, a jak zadba o siebie, to ten Kraków będzie 
dla niego przyjazny” [Anna]. Inna dodaje, że „jeżeli bym chciała coś znaleźć, to bym znalazła" [Iwona]. Pojawiały się równocześnie sugestie, że za ten stan rzeczy niekoniecznie odpowiadają władze miasta oraz polityki publiczne państwa, a sami mieszkańcy Krakowa, którzy często wychodzą z oddolnymi inicjatywami. Za największą pozytywną zmianę respondenci uznali powstawanie nowych ośrodków aktywności dla seniorów z coraz bogatszą ofertą zajęć. Jak podkreśliła jedna z respondentek, ośrodki znajdują się w miarę blisko miejsca zamieszkania każdego seniora, co umożliwia codzienne uczestnictwo w zajęciach bez konieczności dojazdu.

Najczęściej wskazywanymi niedogodnościami były trudności infrastrukturalne, jak odległość do ośrodków, w których organizowane są bardziej specjalistyczne kursy (na przykład skierowane do osób niepełnosprawnych), a przede wszystkim jakość komunikacji miejskiej. Wysokie stopnie, duże natężenie ludzi czy odległość do przystanków były określane jako najważniejsze problemy krakowskiej komunikacji tramwajowej i autobusowej. Według respondentów ich poprawa mogłaby skutkować tym, że więcej seniorów i seniorek mogłoby zaangażować się w zajęcia oferowane poza ich dzielnicą. Architektura starszych krakowskich budynków również była wskazywana jako poważna przeszkoda dla swobodnego poruszania się osób starszych i niepełnosprawnych. Pojawiły się też wypowiedzi wskazujące na złą jakość powietrza, która negatywnie wpływa na funkcjonowanie mieszkańców Krakowa. Smog jest problemem, z którym miasto boryka się już od dłuższego czasu, a osoby starsze, podobnie jak inni mieszkańcy, nie pozostają na to obojętne.

\section{Podsumowanie i rekomendacje}

Chociaż w Krakowie istnieje szeroka oferta zajęć kierowanych do seniorów, to nie potrafi ona przyciągnąć osób starszych dotychczas niezaangażowanych. Nie obejmuje osób z grupy no-go, których mobilność jest ograniczona z uwagi na różne czynniki (bardzo zaawansowany wiek, odległe miejsce zamieszkania, choroby). Wyższą aktywność wykazują kobiety, nie zauważyliśmy jednak wpływu innych cech demograficzno-społecznych na poziom aktywizacji. $Z$ wypowiedzi przedstawicieli badanych instytucji wynika, że za główne czynniki determinujące podjęcie aktywności należy uznać przede wszystkim stan zdrowia oraz cechy charakteru. Najczęściej są to osoby o względnie wysokim poziomie sprawności.

Jesteśmy świadomi ograniczeń, jakimi obarczone są nasze badania. Rekrutując respondentów spośród członków domów aktywizacji senioralnej, dobraliśmy osoby już zaangażowane. Przeprowadzając badania, nie dotarliśmy do osób wykluczonych czy takich, które nie podejmują żadnej aktywności. Wysłuchanie ich zdania jest istotne w świetle planowania przyszłych działań na rzecz aktywizacji seniorów.

Ważne jest również zwrócenie uwagi na instytucjonalne warunki, stereotypizację, stygmatyzację oraz wykluczenie osób starszych, które sprawiają, że przekroczenie przez nich bariery aktywizacji może stać się trudne lub wręcz niemożliwe. Nie powinno się 
zapominać również o znaczeniu zdrowia psychicznego i samooceny seniorów, ponieważ negatywne podejście do samego siebie często może prowadzić do samowykluczenia osób starszych. Starość jest niewątpliwie bardzo wrażliwą kwestią badawczą. Wymaga ona szerszego przeprowadzenia bardziej pogłębionych badań, aby móc w przyszłości stworzyć polityki bardziej odpowiadające potrzebom osób starszych.

\section{Bibliografia}

Active Aging Index - Summary 2014 (2015); https://statswiki.unece.org/display/AAI/VI.+Do cuments+and+publications?preview=/76287849/117178632/extract_for_translation3\%20 updated--.pdf\#expand-Clicktoview2017papers (dostęp: 25.04.2018).

CBOS - Polacy wobec własnej starości, Komunikat z badań BS/94/2012 (2012). CBOS, Warszawa. CBOS - Sposoby spędzania czasu na emeryturze, Komunikat $z$ badań BS/106/2012 (2012). CBOS, Warszawa.

CBOS - Sposoby spędzania czasu przez seniorów, Komunikat z badań 163/2016 (2016). CBOS, Warszawa.

CBOS - Portret społeczno-demograficzny seniorów, Komunikat z badań 160/2016 (2016a). CBOS, Warszawa.

Czapiński J., Błędowski P. (2014). Aktywność społeczna osób starszych w kontekście percepcji Polaków. „Diagnoza społeczna: Raport tematyczny”, Warszawa.

GUS - Informacja o sytuacji osób starszych na podstawie badań Głównego Urzędu Statystycznego (2016). GUS, Warszawa.

GUS - Rocznik demograficzny (2017). GUS, Warszawa.

GUS - Trwanie życia w 2016 r. (2017). GUS, Warszawa.

Babbie E. (2004). Badania społeczne w praktyce, tłum. A. Kloskowska-Dudzińska, W. Betkiewicz. Wydawnictwo Naukowe PWN, Warszawa.

Babbie E. (2008). Podstawy badań społecznych, tłum. W. Betkiewicz et al. Wydawnictwo Naukowe PWN, Warszawa.

Flick U. (2010). Projektowanie badania jakościowego, tłum. P. Tomanek. Wydawnictwo Naukowe PWN, Warszawa.

Golinowska S. (2016). Promocja zdrowia adresowana do osób starszych wśród europejskich strategii wobec starzenia się. ,Problemy Polityki Społecznej”, 34(3): 27-52.

Karpińska K., Dykstra P. (2015). Wskaźnik aktywnego starzenia się i rozszerzenie go na szczebel regionalny. Sprawozdanie syntetyczne, Komisja Europejska, Dyrekcja Generalna ds. Zatrudnienia, Spraw Społecznych i Włączenia Społecznego.

Klimczuk A. (2012). Kapitał społeczny ludzi starych na przykładzie mieszkańców miasta Bialystok. Wiedza i Edukacja, Lublin.

Mucha J., Krzyżowski Ł. (2010). Aging in Poland at the Dawn of the 21st Century. „Polish Sociological Review", 2(170): 247-260.

Okólski M., Fihel A. (2012). Demografia. Wspótczesne zjawiska i teorie. Wydawnictwo Naukowe Scholar, Warszawa. 
Perek-Białas J., Zwierzchowski J. (2014).Wskaźnik aktywnego starzenia w ujęciu regionalnym. Opracowanie dla Departamentu Polityki Senioralnej Ministerstwa Pracy i Polityki Społecznej, Warszawa.

Perek-Białas J. (2016). Tradycyjne i uzupetniające podejścia do ewaluacji efektów polityki senioralnej w Polsce. „Problemy Polityki Społecznej. Studia i Dyskusje. Kwartalnik”, 34(3): 91-111.

Szarota Z. (2004). Gerontologia społeczna i oświatowa. Wydawnictwo Naukowe Akademii Pedagogicznej, Kraków.

Szarota Z. (2013). Era trzeciego wieku -implikacje edukacyjne. „Edukacja Ustawiczna Dorosłych”, 1(84): 7-18.

Szukalski P. (2004). Uprzedzenia i dyskryminacja ze względu na wiek (ageism) - przyczyny, przejawy, konsekwencje. „Polityka Społeczna”, 2: 11-15.

Worach-Kardas H. (1983). Wiek a pełnienie ról społecznych. Wydawnictwo Naukowe PWN, Warszawa-Łódź.

Zych A. (1999). Człowiek wobec starości. Szkice z gerontologii społecznej. Śląsk, Katowice. 